\title{
Manganese Hyperaccumulators and their Hyperaccumulating and Tolerance Mechanisms: A Review of the Current State of Knowledge
}

\begin{abstract}
Pan W-S ${ }^{1}$ Wu K-K ${ }^{2}$, Rajendran $\mathrm{M}^{2}, \mathrm{Li}$ W-C ${ }^{3}$ and Wu C C $^{*}$

${ }^{1}$ College of Bioscience and Biotechnology, Hunan Agricultural University, Changsha, PR China

${ }^{2}$ School of Metallurgy and Environment, Central South University, Changsha, PR China

${ }^{3}$ Department of Science and Environmental Studies, The Education University of Hong Kong, Tai Po, Hong Kong Special Administrative Region, PR China

*Corresponding author: Chuan $\mathrm{Wu}$, School of Metallurgy and Environment, Central South University, Changsha, PR China
\end{abstract}

Received: September 16, 2021; Accepted: October 12, 2021; Published: October 19, 2021

\begin{abstract}
Manganese $(\mathrm{Mn})$ is ubiquitous in the environment due to both geological and human activities. It is essential for plants, as for most other living organisms, but can also be toxic when it is present in excess. Some plant species, referred to as Mn hyperaccumulators, can accumulate over $10000 \mu \mathrm{g} / \mathrm{g}$ of $\mathrm{Mn}$ in their shoot tissues without showing any phytotoxicity. Approximately 24 Mn hyperaccumulators are currently known worldwide. However, ample data is available the $\mathrm{Mn}$ hyperaccumulator species and biological significance of $\mathrm{Mn}$ hyperaccumulation and tolerance mechanisms. To give new insights, this review highlights the current knowledge of Mn hyperaccumulation and tolerance mechanisms in hyperaccumulators, which include root uptake, xylem loading, transport, sequestration, and detoxification processes. Hyperaccumulators uptake Mn mainly accumulates as Mn2+ into the xylem, from which it is then transferred to the shoots. Foliar $\mathrm{Mn} 2+$ is mainly stored in vacuoles, the endoplasmic reticulum, and the Golgi. It is sequestered by organic ligands and some transporter proteins at a subcellular level in the root and shoot, which can allow the plants to exhibit great tolerance. From the in-depth examine the published literature; the main knowledge gap and future research are highlighted. In addition, Mn hyperaccumulator biomass disposal methods and applications also discussed.
\end{abstract}

Keywords: Hyperaccumulator; Manganese; Phytomining; Transporters; Root uptake; Manganese sequestration

\section{Introduction}

Environmental contamination by Manganese (Mn) has become a serious problem worldwide. Manganese is the fifth most abundant metal in nature [1] and is released by electroplating, the petrochemical and fertilizer industries and mining processes [2]. Mining is a main source of Mn contamination in soils [3]. Worldwide manganese ore production resulted in 17.7 million tonnes $(\mathrm{mt})$ of contaminated metals in 2014, representing a production increase of 5.1\% over the previous year. The main producers are South Africa with over $26.4 \%$ of the world production, China with $18.0 \%$, Australia with $17.5 \%$ and Gabon with $11.3 \%$ of the total world production.

Manganese is an important micronutrient for plant growth and plays multiple roles in photosynthesis, nitrogen metabolism, hormone regulation, and the synthesis and breakdown of certain substances [4]. However, Mn accumulation in excess of the normal range of $20-500 \mathrm{mg} / \mathrm{kg}$ of the plant dry weight [5] can have negative effects on plants. Excess Mn inhibits seed germination [6] and plant growth [7], causes biomass loss [8], decreases the photosynthetic rate [9], inhibits root development [10] and hinders the adsorption of other nutrients [11]. Furthermore, Mn toxicity affect the human nervous system and cause parkinsonian syndrome [12].

The removal of excess $\mathrm{Mn}$ from contaminated sites by physical and chemical methods has been unsuccessful in restoring large areas of land due to the high cast, deterioration of soil quality and other problems associated with these methods $[13,14]$. In contrast, phytoremediation is a promising technology for remediating heavy metal-contaminated sites by using hyperaccumulator plants $[15,16]$. The quality of hyperaccumulator species is judged by the following four characteristics: (1) Hyperaccumulation ability (100 times greater metals accumulation than normal plants); (2) Hypertolerance; (3) Bioaccumulation factor $(\mathrm{BF})>1$ and (4) Translocation factor (TF) $>1$ [17]. The first study of a hyperaccumulator plant described the extreme accumulation of nickel by shoots of Sebertia acuminata (new name is Pycnandra acuminata) in New Caledonia [18]. Approximately 500 plant taxa capable of heavy metal accumulation have been identified worldwide [19], among which approximately 330 plant species are Ni hyperaccumulators, and 20 species are $\mathrm{Mn}$ hyperaccumulators $[20,21]$. In this review examines the current knowledge of $\mathrm{Mn}$ hyperaccumulators and their accumulation and tolerance mechanisms, which include root uptake, xylem loading, transport, distribution and detoxification mechanisms. In addition, this review provides information about $\mathrm{Mn}$ hyperaccumulator biomass disposal and applications.

\section{Discover of Manganese Hyperaccumulators}

Numerous studies have aimed on the identification of $\mathrm{Mn}$ hyperaccumulator plants based on tolerance, hyperaccumulation in highly Mn contaminated sites [22-25], hydroponics and pot experiments [22,24,26,27], and microprobe analysis [26,28,29]. A
Ann Agric Crop Sci - Volume 6 Issue 7 - 202

ISSN: 2573-3583 | www.austinpublishinggroup.com

Pan et al. (C) All rights are reserved
Citation: Pan W-S, Wu K-K, Rajendran M, Li W-C and Wu C. Manganese Hyperaccumulators and their Hyperaccumulating and Tolerance Mechanisms: A Review of the Current State of Knowledge. Ann Agric Crop Sci. 2021; 6(7): 1099. 
Mn hyperaccumulator plant is defined as one that accumulates over $10000 \mu \mathrm{g} / \mathrm{g}$ of $\mathrm{Mn}$ in its shoot tissues [30]. Approximately $24 \mathrm{Mn}$ hyperaccumulator plants are currently known worldwide, including 8 species from Cleastraceae, 4 species from Polygonaceae, 3 species each from Myrtaceae and Proteaceae, and 1 species each from Amarantheaceae, Aralicaceae, Apocynaceae, Clusiaceae, Phytolacceae and Theaceae (Table 1). Jaffre [31-33] discovered the first Mn hyperaccumulator plants with $\mathrm{Mn}$ concentrations above $1.0 \%$ in the leaves of Beaupreopsis paniculata, Macadamia neurophylla, Macadamia angustifolia (M. neurophylla and M. angustifolia are now classified as Virotia species), Maytenus fournieri, Macadamia sebertiana, Garcinia amplexicaulis and Eugenia clusioides, all in New Caledonia. In addition, Brooks et al. [34] analysed 31 species in Alyxia from New Caledonia for their Mn content and found that Alyxia rubricalis showed the highest Mn uptake (1.15\%) in dried leaves. Twenty years later, Bidwell et al. [28] identified the first native Australian Mn hyperaccumulator, Gossia bidwillii (formerly Austromyrtus bidwillii); Mn concentrations upto $19200 \mu \mathrm{g} / \mathrm{g}$ and $26509 \mu \mathrm{g} / \mathrm{g}$ were measured in the dried leaves of this rain forest tree. Similarly, Xue et al. [22] identified the first native Chinese Mn hyperaccumulator species (Phytolacca acinosa), which accumulate $19300 \mu \mathrm{g} / \mathrm{g}$ Mn in shoot tissue. Despite, now P. acinosa is identified as Phytolacca americana L., P. acinosa Roxb based on the morphological characteristics [35]. Yang et al. [26] conducted a potted plant experiment to illustrate the $\mathrm{Mn}$ accumulation and tolerance ability of Schima superba. The results showed that $\mathrm{S}$. superba accumulated $62412.3 \mathrm{mg} / \mathrm{kg} \mathrm{Mn}$ in the stem under $150 \mathrm{mmol} / \mathrm{l}$ treatment, and when the high $\mathrm{Mn}$ supply $40 \mathrm{mmol} / \mathrm{L}$. The $\mathrm{Mn}$ concentration in shoot exceeded $10000 \mathrm{mg} / \mathrm{kg}$, which is suggested concentration for Mn hyperaccumulation. Fernando et al. [29] identified five new Mn hyperaccumulators, namely, Maytenus cunninghamii, Gossia bamagensis, Gossia fragrantissima, Gossia sankowsiorum, and Gossia gonoclada, in Australia. Between 2010 and 2016, additional new Mn hyperaccumulators, $P$. pubescens [36], P. perfoliatum [37], Celosia argentea [27], Eucalyptus grandis $\dot{\mathrm{x}}$ Eucalyptus urophylla [38] and Polygonum lapathifolium [39], were discovered in China.

\section{Manganese Phytoavailable Hyperaccumulation}

\section{Rhizosphere mobilization of Manganese}

Manganese occurs in the soil in oxidation forms including $\mathrm{Mn} 1+, \mathrm{Mn} 2+, \mathrm{Mn} 3+, \mathrm{Mn} 4+, \mathrm{Mn} 6+$ and Mn7+. Among them, the most phytoavailable form is $\mathrm{Mn} 2+$, and the most easily reducible forms are Mn3+ and Mn4+ [40]. Mn phytoavailability is influenced by $\mathrm{pH}$, microorganisms, organic matter content, cation-exchange capacity and interactions with other metals (physiological and metabolic characteristics of the plant) [41]. A low soil pH (acid soil) can increase the redox potential [42] and phytoavailability of $\mathrm{Mn}$ [43-45]. At higher soil $\mathrm{pH}(>8.0), \mathrm{Mn} 2+$ can auto-oxidize and will form $\mathrm{MnO}_{2}, \mathrm{Mn}_{2} \mathrm{O}_{3}$ and $\mathrm{Mn}_{3} \mathrm{O}_{4}$, which are not available for plants [46,47]. For example, $\mathrm{Xu}$ et al. [48] reported that P. americana root achieved its maximum $\mathrm{Mn}$ adsorption at $\mathrm{pH}$ 5-6, while at $\mathrm{pH}$ values above 6, Mn adsorption decreased, probably because of the formation of hydroxide complexes. Most of Mn hyperaccumulator plants have been identified in areas with metal-rich and low-pH areas soils. For instance, the Phytolacca species were discovered in metal-rich and low-pH (4.8) soil in Xianglan, China, in manganese tailings [22,35] and in the Roberts Mn mine in Cherokee County, South Carolina, USA [49]. Because, the hyperaccumulator plants rhizospheres have some influence on phytoavailability of heavy metals by release of exudates (carboxylates) and acidification of rhizosphere. For example, Godo and Reisenauer [50] reported that plant roots were released exudates (hydroxycarboxylase), which increased the phytoavailability of $\mathrm{Mn}$ in rhizosphere soil. Lambers et al. [45] showed that $P$. americana released protons into the rhizosphere in order to enhance the phosphate solubility, resulting in coincidental mobilization of Mn. Similarly, a comparative study showed that $P$. americana acidifies the rhizosphere soil and enhance Mn solubility more than Acalypha rhomboidea (non-accumulating) plant [51].

Moreover, rhizosphere microorganisms also have some great potential to reduce $\mathrm{MnO}_{2}$ into phytoavailable $\mathrm{Mn} 2+$ by producing certain chelators and siderophores [52] that alter the soil $\mathrm{pH}$ and enhance chelation efficacy. For example, bacteria (Bacillus manganica) and fungi (Mycogone, Tricholadium) can reduce Mn4+ to $\mathrm{Mn} 2+$, which is the form required by plants. Meanwhile, some rhizosphere bacteria, namely, Pseudomonas and Geobacter, reduce oxidized $\mathrm{Mn} 4+$ to Mn2+, affecting its availability to the plants $[41,53,54]$.

\section{Manganese Uptake and Translocation from Roots-To-Shoots}

Uptake and translocation of $\mathrm{Mn}$ from roots to shoots are dependent on several steps: (i) Root uptake, (ii) Xylem loading and (iii) Transport and distribution $[46,55]$.

\section{Root uptake}

Bioavailable $\mathrm{Mn} 2+$ uptake by roots is generally exhibited as two phase processes, apoplastic binding phase and symplastic uptake [56]. Apoplastic binding is an initial, non-metabolic and rapid uptake phase $[47,57]$. In this phase, Mn2+ absorbed by root cells, which have a negatively charged cell wall that is strongly attractive to divalent cations such as $\mathrm{Ca} 2+, \mathrm{Fe}, \mathrm{Zn}$ and $\mathrm{K}[58,59]$. Interactions between $\mathrm{Mn} 2+$ and other divalent cations have been noted during the root uptake processes. For example, Peng et al. [60] studied the uptake of $\mathrm{Mn}$ and its interaction with Cd in P. americana and showed that the $\mathrm{Cd}$ addition can decreased the Mn uptake in the root and increased it in the stem. The Mn and Cd interaction in plant uptake indicated that $P$. americana might be use the same transport proteins for the uptake of these metal ions. Dou et al. [61] mentioned that the uptake and transport of $\mathrm{Mn}$ are closely related to those of $\mathrm{Ca}$ in P. americana because the ionic radius, charge and coordination chemistry properties of $\mathrm{Ca}$ and $\mathrm{Mn}$ are similar. Bidwell et al. [28] reported that the Mn hyperaccumulators Alyxia sp. and Austromyrtus bidwillii accumulate $\mathrm{Mn}$ at the expense of $\mathrm{Ca}$ and $\mathrm{Mg}$. All of the above studies indicate that $\mathrm{Mn}$ transport pathway might be involved in the uptake of $\mathrm{Ca}, \mathrm{Cd}$ and $\mathrm{Mg}$. In addition, the low $\mathrm{Fe} / \mathrm{Mn}$ ratio in $P$. americana noticed a high concentration of Mn uptake from soil [60]. Pedas et al. [62] reported that phosphate directly interferes with Mn uptake by causing alterations in membrane transporter. Xu et al. [58] also suggested that $\mathrm{P}$ and $\mathrm{S}$ probably played important roles in $\mathrm{Mn}$ absorption by $P$. acinosa a hyperaccumulator plant. A similar $\mathrm{Mn}$ uptake pattern seems to exist in $\mathrm{Ni}$ hyperaccumulators. For example, the Ni hyperaccumulators Alyssum murale and Alyssum corsicum accumulate the greatest $\mathrm{Mn}$ concentration upon receiving $\mathrm{Ni} / \mathrm{Mn}$ treatment, but $\mathrm{Ni}$ uptake is inhibited by the addition of $\mathrm{Mn}$. This 


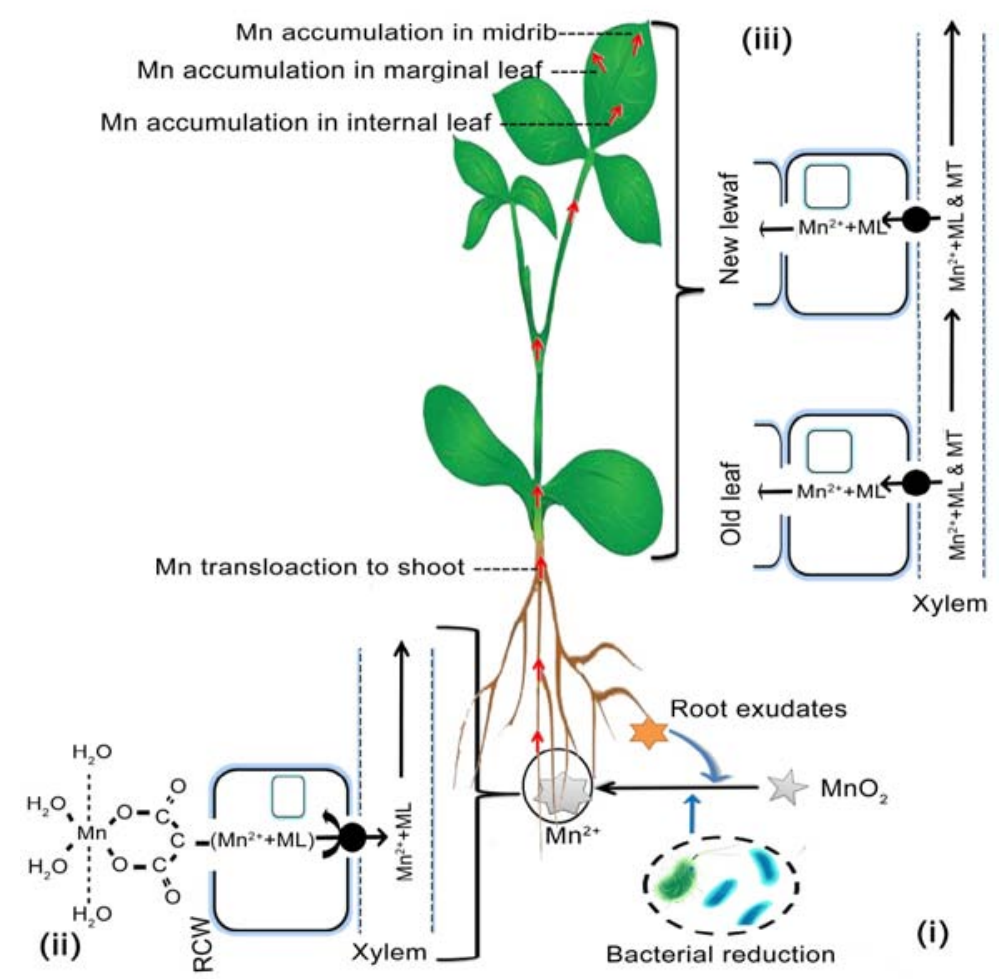

Figure 1: General mechanism of Mn hyperaccumulation in a hyperaccumulator, which includes (i) Mn solubilization in the rhizosphere; (ii) Mn root uptake and xylem loading; and (iii) Mn translocation from root to shoot. ML: Metal Ligands; MT: Metal Transporters; RCW: Root Cell Wall.

result suggests that Ni does not interfere with Mn uptake. Ghaderian et al. [63] showed that the Ni uptake of Alyssum bracteatum (a Ni hyperaccumulator) was inversely correlated with $\mathrm{Mn}$, and likewise, Mn uptake was inversely correlated with $\mathrm{Ni}$ in the growth medium, suggesting competition between $\mathrm{Ni}$ and $\mathrm{Mn}$ for uptake at the roots.

Far less is known regarding the molecular mechanism by which Mn binds to root cell wall during the process of uptake. For example, Kopittke et al. [64] showed that Mn binds to a carboxylic group of cowpea root cell wall, which was confirmed by using Mn K-edge XANES spectroscopy. This carboxylic group exists in multiple components of the root cell wall, including pectin, cellulose and lignin [65]. Similarly, Xu et al. [48] used FTIR spectral analysis to show that $\mathrm{C}-\mathrm{O},=\mathrm{C}-\mathrm{O}$ and $-\mathrm{OH}$ functional groups are the main binding sites for $\mathrm{Mn}$ on the root cell wall of $P$. americana. These study results indicate that $\mathrm{Mn} 2+$ can bind carboxylic and hydroxylic groups of the root cell wall in both hyperaccumulators and non-hyperaccumulator plants during the uptake process (Figure 1). Further detailed experiments are needed to reveal the specific compounds in the root cell walls that are responsible for $\mathrm{Mn}$ binding in hyperaccumulators.

$\mathrm{Mn}$ uptake also appears to involve metal transporters. For example, a group of Natural Resistance-Associated Macrophage Protein (NRAMP) transporters including OsNramp5 are involved in $\mathrm{Mn}$ uptake on the root surface of rice plants [66,67]; likewise, Cailliatte et al. [68] reported that the AtNramp1 (high-affinity) transporter is involved in $\mathrm{Mn}$ uptake by the roots of Arabidopsis thaliana. Takahashi and Sugiura [69] showed that transgenic tobacco transformed with tomato root protein (LeGlp1) with a metal binding site at its $\mathrm{N}$-terminus specifically binds $\mathrm{Mn}$ with the recombinant
LeGlp1 protein. This binding of Mn to LeGlp1 strongly suggests the involvement of LeGlp1 in Mn uptake from the soil at the root plasma membranes, suggesting in turn that $\mathrm{Mn}$ uptake in hyperaccumulators might be associated with Mn-specific transporters such as the NRAMP and ZIP proteins. Liu et al. [27] reported that hyperaccumulative Mn uptake in Celosia argentea might be mediated by NRAMP or ZIP transporters.

\section{Xylem loading transport and distribution}

Manganese can reach the xylem through symplast pathway and occurs there both as free ions $(\mathrm{Mn} 2+)$ and in complex with organic acids. For example, Williams and Pittman [70] mentioned that in soybean and tomato, approximately $60 \%$ of the xylem $\mathrm{Mn}$ was in the form of $\mathrm{Mn} 2+$ and is complexed with citrate or malate. Duo et al. [71] showed that $\mathrm{Mn}$ is complexed with oxalic acid in P. americana root. Similarly, $\mathrm{Mn}$ is associated with citrate in the root of the nonhyperaccumulator cowpea [64]. These results indicate that $\mathrm{Mn}$ is present as $\mathrm{Mn} 2+$ and complexed with organic acids in the root xylem of both hyperaccumulators and non-hyperaccumulators (Figure 2). Far less information is available on membrane transporters in $\mathrm{Mn}$ loading in the xylem. For instance, it has been suggested that plasma membrane-localized NRAMP 1\&5 [68] and IRT1 [72] transporters are involved in Mn transport in Arabidopsis. Likewise, ZmYS1 and HvYSL2 can transport Mn in maize and barley $[73,74]$.

Manganese influx into the leaf symplast occurs across the plasma membrane of the leaf cell [75]. Studies on non-hyperaccumulators have reported that $\mathrm{Mn}$ is absorbed by leaf cell membrane transporters such as the IRT family and thereby transported to the cytosol [72]. The higher expression levels of NRAMP proteins and ZIP protein in 


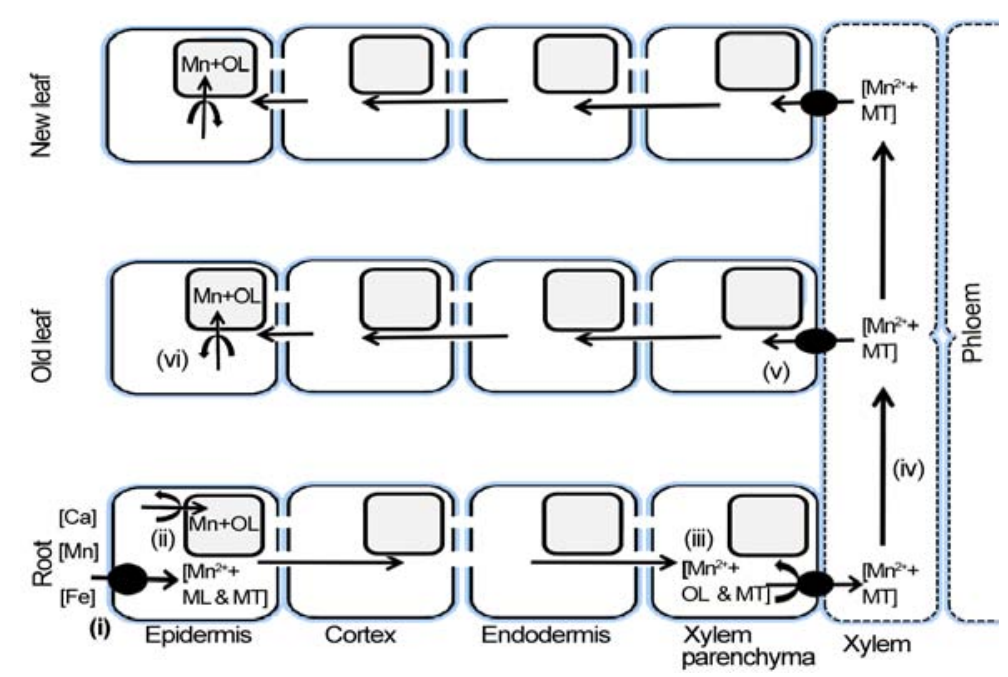

Figure 2: Hypothetical model for Mn tolerance processes in hyperaccumulator plants. (i) Root uptake, (ii) root sequestration, (iii) xylem loading and translocation to shoot, (iv) xylem transport, (v) transport and distribution in leaf, and (vi) foliar sequestration. ML: Metal Ligands; MT: Metal Transporters; OL: Organic Ligands; Mn influx and Mn efflux.

the cambium could transfer higher levels of $\mathrm{Mn}$ from the roots to the shoots [76]. In addition, Gustin et al. [77] reported that cation diffusion facilitator/metal tolerance protein (CDF/MTP) could transport Mn2+ into subcellular compartments or out of the cytoplasm. The Mn-CDF transporter was first identified in the hyperaccumulator Stylosanthes hamata [78]. Xie et al. [38] reported that high concentration of Mn accumulated in stem xylem vessel of $E$. grandis $\times E$. urophylla. This result indicated that in $\mathrm{Mn}$ hyperaccumulator plants $\mathrm{Mn}$ mostly transported by xylem vessel and distributed to stem other parts. These studies suggested that IRT, NRAMP, ZIP and CDF/MTP transporters might be involved in Mn transport from root to the shoot in both hyperaccumulators and non-hyperaccumulators.

After the influx of $\mathrm{Mn}$ in leaf symplast, then distributed into various parts of the cells. $\mathrm{Xu}$ et al. [58] showed $\mathrm{Mn}$ uptake and distribution in the epidermis, cortex, endodermis and vascular bundles of the root cross section of $P$. acinosa. These results showed that $\mathrm{Mn}$ content decreased from the epidermis to the cortex and increased from the cortex to the vascular bundles via the endodermis, indicating the translocation of $\mathrm{Mn}$ from the cortex to the vascular bundles by an osmotic process). It is concluded that Mn transport exhibits some similarities to active transportation. Furthermore, Mn is transported to photosynthetically active leaves [79], showing that $\mathrm{Mn}$ is a most important plant nutrient for photosynthesis. Xie et al. [38] showed that high concentration of Mn distribution in leaf cross section, photosynthetic palisade and spongy tissue of Eucalyptus grandis $\times$ E. urophylla. Similarly, Fernando et al. [80] reported that $\mathrm{Mn}$ was evenly distributed in entire leaf cross section and photosynthetic tissues as well as in the palisade and spongy mesophyll of Gossia. Menon emphasized mesophyll cells is the major storage site of $\mathrm{Mn}$ in hyperaccumulator plants namely $P$. americana and $A$. sciadophylloides. In contrast, high Mn distribution has been observed in non-photosynthetic cells of M. fournieri $[81,82]$. Xu et al. [58] showed that a higher Mn concentration was found in the leaf margin than near the midrib regardless of the total Mn content of individual leaves of $P$. acinosa; consequently, Mn concentrations reduced from the palisade tissue to the spongy tissue in the mesophyll. To date, no data are available to explain the why hyperaccumulators have different Mn transporters and Mn distribution patterns. Therefore, further detailed experiments are needed for a clear understanding of these processes in Mn hyperaccumulators.

\section{Manganese Tolerance Mechanisms}

Hyperaccumulator plants have evolved several tolerance mechanisms to protect their normal growth and developments while under heavy metal ions stress [17]. Generally, Mn hyperaccumulators employ various tolerance mechanisms to detoxify Mn toxicity, such as translocation, sequestration and enhanced the production of antioxidants [44,55].

\section{Root Sequestration Processes}

Upon reaching the root apoplast, manganese is complexed by organic acids to alleviate its toxicity [56]. For example, oxalate and malate are favourable for $\mathrm{Mn}$ complexation in plant tissues and play a crucial role in Mn hyperaccumulation and detoxification in hyperaccumulator plants $[71,83]$. The total oxalic acid concentration was found to be higher than the Mn content in the root of $P$. americana (a Mn hyperaccumulator) [71]. This study indicated that oxalic acid could increase Mn tolerance and Mn hyperaccumulation in hyperaccumulators. In contrast, Kopittke et al. [64] estimated that $80 \%$ of the $\mathrm{Mn} 2+$ in roots could bind with citrate in cowpea (a nonhyperaccumulator). Similarly, Fernando et al. [83] showed that Mn is related with citrate rather than oxalate in Mn hyperaccumulators. Therefore, it may be concluded that both oxalate and citrate are involved in $\mathrm{Mn}$ sequestration in the root and can enhance $\mathrm{Mn}$ tolerance in both hyperaccumulators and non-hyperaccumulator plants (Figure 2).

\section{Foliar Mn Sequestration}

Foliar $\mathrm{Mn}$ in hyperaccumulators occurs mostly in soluble form $(\mathrm{Mn} 2+)$, complexed with organic ligands, and sequestered in vacuoles $[28,83]$. The sequestration of $\mathrm{Mn}$ in vacuoles is one of the important detoxification mechanisms in Mn hyperaccumulators 


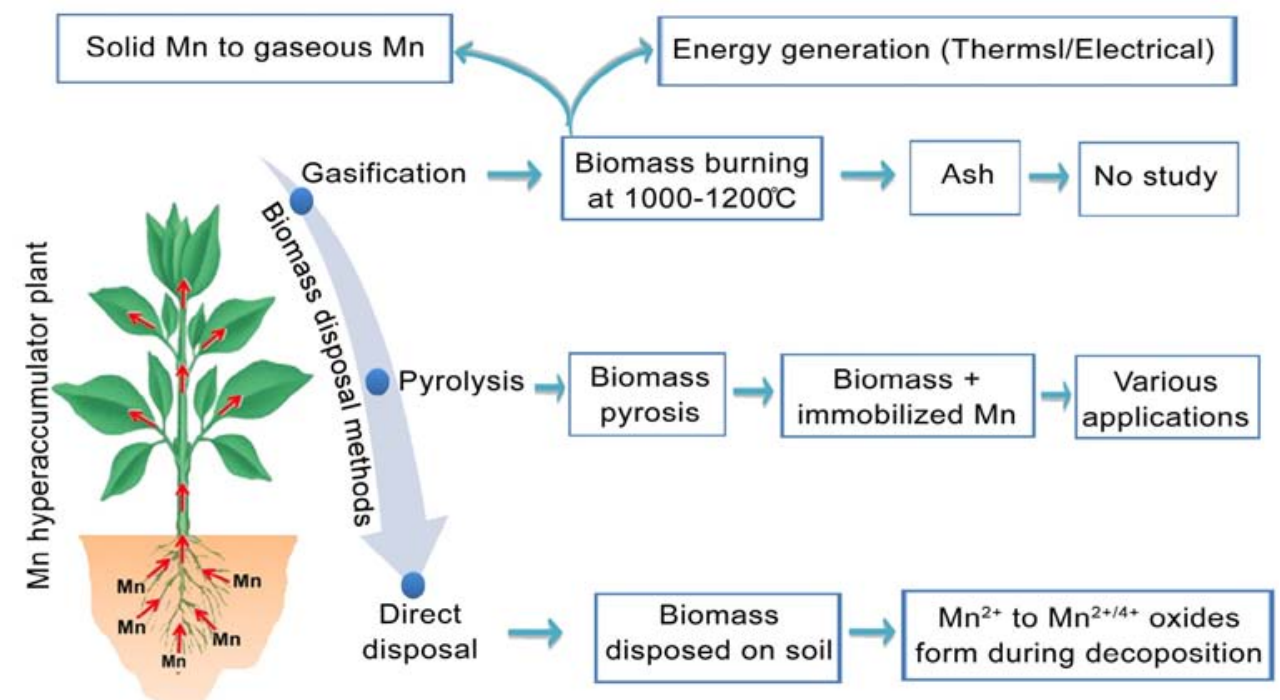

Figure 3: Schematic diagram of disposal methods for Mn hyperaccumulator biomass.

[71,84]. For example, Fernando et al. [82] reported that major Mn sequestration processes occurred primarily in the vacuoles of three Mn hyperaccumulator plants, namely, Virotia neurophylla, Maytenus fournieri and Garcinia amplexicaulis. Similarly, it has been reported that excess Mn accumulates in the leaves of Gossia bidwillii (a Mn hyperaccumulator) and is primarily sequestered in the vacuoles of palisade cells and photosynthetic tissues [85]. In contrast, Fernando et al. [86] found high Mn accumulation in non-photosynthetic cells of leaf epidermal tissues of $M$. founieri. Therefore, Mn hyperaccumulators can sequester excess of $\mathrm{Mn}$ in both non-photosynthetic tissues and photosynthetic tissues [41]. Further, the sequestration of foliar Mn by organic ligands at the subcellular level confers great tolerance on $\mathrm{Mn}$ hyperaccumulators $[83,87]$. Mn has been reported to be associated with oxalate in the freeze-dried leaves of $P$. acinosa [88]. Similarly, Mn-oxalate complexes were showed in the leaves of $P$. americana [89].

\section{Antioxidative Defense System}

Generally, the high concentration of Mn causes Reactive Oxygen Species (ROS) in plants [90] and affects the plant metabolism and growth [9]. Although, hyperaccumulators have effective antioxidative defense system to scavenging the heavy metals induced ROS. The antioxidative defense system comprising antioxidative enzymes such as Superoxide Dismutase (SOD), Catalase (CAT), Peroxidase (POX), Ascorbate Peroxidase (APX) and nonenzymatic low molecular mass antioxidants. For example, a Mn hyperaccumulator P. lapathifolium can maintain high SOD, CAT and APX activities in both root and shoot tissues under the Mn toxicity condition, which implied that $P$. lapathifolium might have highly effective ROS scavenging mechanisms. Gao et al. [91] reported that Mn treatment increase the laccases activity and lignin content, but reduces SPOD activity and phenolics concentrations in apoplastic washing fluid of $P$. americana leaves. These results suggested that lignin formation by laccases and decreased POD activity are involved in the Mn tolerance mechanisms of $P$. americana. Zhao et al. [92] showed that $P$. americana have great ability to protect redox homeostatic disturbance and cellular damages by enhancing their SOD and CAT activities under the Mn toxicity condition. Furthermore, the excess Mn decreased POX and APX activities these may reduce the ROS generation in P. americana. Weng et al. [93] observed that excess Mn increased the SOD, CAT and APX activities in P. acinosa. The increased SOD activity could be scavenged $\mathrm{O}_{2}^{-}$and produced $\mathrm{H}_{2} \mathrm{O}_{2}$. This $\mathrm{H}_{2} \mathrm{O}_{2}$ can be scavenged by increased CAT and APX activities. These results suggested that increased SOD, CAT and APX activities could be reduced oxidative stress in $P$. acinosa under the excessive Mn concentration. Previous studies have been reported that a modulation of antioxidative enzymes (SOD, CAT, POX and APX) activities occurs in response to $\mathrm{Mn}$ induced oxidative stress. But no information is available on gene expression of these antioxidative enzymes isoforms. Indeed all the antioxidative enzymes have isoezymes, which may be involved in regulatory mechanisms to heavy metals induced oxidative stress and play role in protecting all the organelles [94]. Therefore, it is most important to understand the role of isoenzymes in regulatory mechanism to excessive Mn toxicity in plants.

\section{Role of Rhizosphere Microorganisms}

The hyperaccumulators rhizosphere microorganisms could modify the heavy metal phytoavailability, accumulation and protect the plants from metal toxicity [95]. The rhizosphere of hyperaccumulator plant is consist of many heavy metal resistance endophytic bacteria [59], which significantly increases the uptake of heavy metals and root elongation. Endophytic bacteria producing phytohormones, siderophore, and 1-aminocyclopropane-1-carboxylate (ACC) deaminase under the metal contaminated environment and these are promote the plant growth and increase heavy metal induced toxicity tolerance. A study isolated IAA and siderophore producing bacteria in leaves and ACC producing bacteria in root tissues of Mn hyperaccumulator ( $P$. americana) under the Mn contaminated soils. These endophytic bacteria enhance the root growth (ranging from $6.4 \%$ to $18.3 \%$ ) and above ground tissues (ranging from $19.3 \%$ to $70.2 \%$ ) and $\mathrm{Mn}$ uptake (64\%) in penisetum grown under Mn added soil [96]. This study concluded that endophytic bacteria 
Table 1: List of manganese hyperaccumulator plants discovered worldwide.

\begin{tabular}{|c|c|c|c|}
\hline Plant species & Plant family & Location & References \\
\hline Beaupreopsis paniculata & Proteaceae & New Caledonia & Jaffre [33] \\
\hline Denhamia fournieri & Cleastraceae & New Caledonia & Jaffre [33] \\
\hline Macadamia neurophylla & Proteaceae & New Caledonia & Jaffre [31] \\
\hline Eugenia clusioides & Myrtaceae & New Caledonia & Jaffre [32] \\
\hline Garcinia amplexicaulis & Clusiaceae & New Caledonia & Jaffre [32] \\
\hline Macadamia angustifolia & Proteaceae & New Caledonia & Jaffre [32] \\
\hline Maytenus fournieri & Celastraceae & New Caledonia & Jaffre $[32,33]$ \\
\hline Macadamia sebertiana & Celastraceae & New Caledonia & Jaffre [32] \\
\hline Alyxia rubricalis & Apocynaceae & New Caledonia & Jaffre [33] \& Brooks et al. [34] \\
\hline Gossi bidwillii & Myrtaceae & Australia & Bidwell et al. [28] \\
\hline Phytolacca americana & Phytolaccaceae & China & Xue et al. $[22,35]$ \\
\hline Polygonum hydropiper & Polygonacceae & China & Wang et al. [23] \\
\hline Schima superba & Theaceae & China & Yang et al. [26] \\
\hline Chengiopanax sciadopylloide & Aralicaceae & Japan & Mizuno et al. 2008 \\
\hline Maytenus cunninghamii & Celastraceae & Australia & Fernando et al. [29] \\
\hline Gossia bamagensis & Celastraceae & Australia & Fernando et al. [29] \\
\hline Gossia fragrantissima & Celastraceae & Australia & Fernando et al. [29] \\
\hline Gossia sankowsiorum & Celastraceae & Australia & Fernando et al. [29] \\
\hline Gossia gonoclada & Celastraceae & Australia & Fernando et al. [29] \\
\hline Polygonum pubescens & Polygonacceae & China & Hua et al. [36] \\
\hline Polygonum perfoliatum & Polygonacceae & China & Liu et al. [37] \\
\hline Celosia argentea & Amarantheaceae & China & Liu et al. [27] \\
\hline Eucalyptus grandis x Eucalyptus urophylla & $\begin{array}{l}\text { Myrtaceae } \\
\text { Myrtaceae }\end{array}$ & $\begin{array}{l}\text { China } \\
\text { China }\end{array}$ & $\begin{array}{l}\text { Xie et al. [38] } \\
\text { Xie et al. [38] }\end{array}$ \\
\hline Polygonum lapathifolium & Polygonacceae & China & Kehui et al. [39] \\
\hline
\end{tabular}

enhanced metal toxicity tolerance ability in plants by producing of ACC deaminase under the toxic metal stressed condition. Glick and Penrose and Glick et al. claimed that endophytic bacteria produced ACC deaminase can metabolize into-ketobutyric acid and ammonia then lowering the ethylene level in plants and promote plant growth under the heavy metal stress. Yuan et al. showed that number of endophytic bacterial community associated with $P$. americana in $\mathrm{Mn}$ polluted mining sites [97]. This is indicated that endophytic bacteria have $\mathrm{Mn}$ tolerance and play an important role in plant growth. This study has shown that endophytic bacteria are able to improve the $\mathrm{Mn}$ stress tolerance mechanisms in P. americana. However, less attention has been paid to the root environment of hyperaccumulator and endophytic bacteria, but more studies are needed to ascertain this. On the other hand numerous researchers have highlighted that, Arbuscular Mycorrhizal Fungi (AMF) can enhance the heavy metal tolerance ability in host plants [98]. In addition, AMF can enhance the heavy metal accumulation and biomass levels in hyperaccumulators. Miransari mentioned that, AMF could increase the growth of their host plants by enhance the water and nutrients uptake. Yuan et al. investigated the diversity of AMF species in the rhizosphere and root of $P$. americana grown under the high $\mathrm{Mn}$ contaminated mining area.

\section{Conclusions and Scope of Future Research}

Manganese hyperaccumulators have evolved highly efficient physiological mechanisms for the uptake of Mn by their roots, followed by xylem loading, translocation to the shoots and detoxification. The $\mathrm{Mn}$ is mainly accumulated as $\mathrm{Mn} 2+$ and then loaded into the xylem, transferred to the shoot. During the process of $\mathrm{Mn} 2+$ uptake, $\mathrm{Mn} 2+$ can bind carboxylic and hydroxylic groups in the root cell wall of hyperaccumulators. Manganese uptake and transport are closely related to the uptake and transport of $\mathrm{Ca}$ and Fe. The presence of high levels of oxalate and citrate are involved in $\mathrm{Mn}$ sequestration in the roots. Foliar $\mathrm{Mn} 2+$ is mainly stored in vacuoles, the endoplasmic reticulum and the Golgi. It is sequestered by organic ligands and some transporter proteins at a subcellular level in shoots, which confers great tolerance on the plants. Pyrolysis is a suitable method for the disposal of Mn hyperaccumulator biomass. Phytomining is a novel technology for the recovery of $\mathrm{Mn}$ from plant biomass to be used for industrial applications.

This review has focused on the recent progress in understanding the mechanisms of hyperaccumulation and tolerance in hyperaccumulators. On the basis of the recent literature, a picture emerges of $\mathrm{Mn}$ uptake, transport and detoxification in hyperaccumulator plants. However, some aspects have not yet been fully understood, particularly at the molecular and genetic level. Moreover, the following research gap needs to be further explored.

- There is very less number of Mn hyperaccumulator plant 
species have been identified. Therefore, more plant species need to be explored for Mn hyperaccumulation.

- Detailed research is required for understanding the underlying mechanism of $\mathrm{Mn}$ hyperaccumulation and their response to changing $\mathrm{Mn}$ levels in the environmental.

- There are no report is available on transporters role in uptake, translocation, distribution and detoxification in $\mathrm{Mn}$ hyperaccumulators. Hence, it is necessary for Mn hyperaccumulation.

- In some Mn hyperaccumulators, Mn deposited in nonphotosynthetic tissues for the detoxification process, but no data are available to explain why different hyperaccumulators have different Mn distribution patterns. Therefore, further detailed experiments are needed for a clear understanding of these processes in $\mathrm{Mn}$ hyperaccumulators.

- More research is required to increase the understanding of the sequestration of Mn in root and leaf cells of Mn hyperaccumulators.

- The excessive Mn cause toxicity to plants by producing ROS, which affects plant growth and metabolism. However, the mechanism of antioxidative defines system in Mn hyperaccumulators are not well known. Some studies have been reported that modulation of antioxidative enzymes (SOD, CAT, POX and APX) activities occur in response to $\mathrm{Mn}$-induced oxidative stress. But no information is available on gene expression of these antioxidative enzymes isoforms.

\section{Acknowledgment}

This work was supported by the Research Foundation of Education Bureau of Hunan Province, China (No. 20A246), Natural Science Foundation of Hunan Province of China (No. 2021JJ30340), National Natural Science Foundation of China (No. 31670955), and Dean's Research Fund 2020/21 (Project code: 04626) of the Education University of Hong Kong.

\section{References}

1. Bjorklund G, Chartrand MS, Aaseth J. Manganese exposure and neurotoxic effects in children Environ Res. 2017; 155: 380-384.

2. Veliz GD, Mora S, Go mez P, Dossi MT, Montie J, Arriagada C, et al Behavioral effects of manganese injected in the rat sub stantianigra are potentiated by dicumarol, DT-diaphoras inhibitor. Pharmacol Biochem. 2004 7: 245-251.

3. Singh A, Zeng DH, Chen FS. Heavy metal concentrations in redeveloping soi of mine spoil under plantations of certain native woody species in dry tropical environment, India. J Environ Sci. 2005; 17: 168-174.

4. Garcia CG, Puente LSDL. The absorption of manganese (III) in oat plants Plant Soil. 1977; 47: 229-237.

5. Lei YB, Chen K, Tian XR, Korpelainen H, Li CY. Effect of Mn toxicity on morphological and physiological changes in two Populus cathayana populations originating from different habitats. Trees. 2007; 21: 569-580.

6. Leiva N, Calderon C, Castro S. Differential effect of manganese on the germination of Triglochin striata (Juncaginaceae) and Cotula coronopifolia (Asteraceae) in Laguna de Carrizal Bajo wetland, Atacama Region, Chile. Gayana Bot. 2016; 73: 161-165.

7. Lee $\mathrm{TJ}$, Luitel $\mathrm{BP}$, Kang $\mathrm{WH}$. Growth and physiological response to manganese toxicity in Chinese cabbage (Brassica rapa L. ssp. campestris). Horticul Environ Biotech. 2011; 52: 252-258.

8. Kosiada $T$. The effects of manganese and other factors on the formation of spots on leaves of barley (Hordeum vulgare L.). Fresenius Environ Bul. 2013; 22: $1132-1138$.
9. Nable RO, Houtz RL, Cheniae GM. Early inhibition of photosynthesis during development of Mn toxicity in tobacco. Plant Physiol. 1988; 86: 1136-1142.

10. Lidon F. Rice plant structural changes by addition of excess manganese. J Plant Nutri. 2002; 25: 287-296.

11. Paschke MW, Valdecantos A, Redente EF. Manganese toxicity thresholds for restoration grass species. Environ Pollut. 2005; 135: 313-322.

12. Kwakye GF, Paoliello MMB, Mukhopadhyay S, Bowman AB, Aschner M. Manganese-induced parkinsonism and Parkinson's disease: shared and distinguishable features. Inter J Env Res Pub Heal. 2015; 12: 7519-7540.

13. Salt DE, Blaylock M, Kumar PBAN, Dushenkov V, Ensley BD, Chet I, et al. Phytoremediation: a novel strategy for the removal of toxic metals from the environment using plants. Biotechnol. 1995; 13: 468-474.

14. Memon AR, Aktoprakligil D, Özdemir A, Vertii AM. Heavy metal accumulation and detoxification mechanisms in plants. Turk J Bot. 2001; 25: 111-121.

15. Fellet G, Marchiol L, Perosa D, Zerbi G. The application of phytoremediation technology in a soil contaminated by pyrite cinders. Ecol Eng. 2007; 31: $207-$ 214.

16. Bouwman LA, Bloem J, Romkens PFAM, Japenga J. EDGA amendment of slightly heavy metal loaded soil affects heavy metal solubility, crop growth and microbivorous nematodes but not bacteria and herbivorous nematodes. Soil Biol Bioche. 2005; 37: 271-278.

17. Sun YB, Zhou QX, Wang L, Liu WT. Cadmium tolerance and accumulation characteristics of Bidens pilosa L. as a potential Cd-hyperaccumulator. J Hazard Mater. 2009; 161: 808-814.

18. Jaffre T, Brooks RR, Lee J, Reeves RD. Sebertia acuminata: a hyperaccumulator of nickel from New Caledonia. Sci. 1976; 193: 579-580.

19. Kramer U. Metal hyperaccumulation in plants. Annu Rev Plant Biol. 2010; 61: 517-534.

20. Reeves RD. Tropical hyperaccumulators of metals and their potential for phytoextraction. Plant Soil. 2003; 249: 57-65.

21. Moosavi AA, Ronaghi A. Influence of foliar and soil applications of iron and manganese on soybean dry matter yield and iron-manganese relationship in a Calcareous soil. Aust J Crop Sci. 2011; 5: 1550-1556.

22. Xue SG, Chen YX, Reeves RD, Baker AJM, Lin Q, Fernando DR. Manganese uptake and accumulation by the hyperaccumulator plant Phytolacca acinosa Roxb. (Phytolaccaceae). Environ Pollut. 2004; 131: 393-399.

23. Wang H, Tang SM, Liao XJ, Cao Q, Yang A, Wang TZ. A new manganesehyperaccumulator: Polygonum hydropiper L. Ecol Environ. 2007; 16: 830834.

24. Min Y, Boqing T, Meizhen T, Aoyama I. Accumulation and uptake of manganese in a hyperaccumulator Phytolacca americana. Miner Engi. 2007; 20: $188-190$

25. Deng $\mathrm{H}$, Li MS, Chen $\mathrm{YX}$. Accumulating characteristics of manganese by Polygonum pubescens Blume. J Guangxi Norm Univ Nat Sci Ed. 2010; 28: 58-62.

26. Yang SX, Deng H, Li MS. Manganese uptake and accumulation in a woody hyperaccumulator, Schima Superba. Plant Soil Environ. 2008; 54: 441-446.

27. Liu J, Shang L, Zhang X, Zhu Y, Yu K. Mn accumulation and tolerance in Celosia argentea Linn.: A new Mn-hyperaccumulating plant species. J Hazard Mater. 2014; 267: 136-141.

28. Bidwell SD, Woodrow IE, Batianoff GN, Sommer Knudsen J. Hyperaccumulation of manganese in the rainforest tree Austromyrtus bidwillii (Myrtaceae) from Queensland, Australia. Funct Plant Biol. 2002; 29: 899-905.

29. Fernando DR, Guymer G, Reeves RD, Woodrow IE, Baker AJ, Batianoff GN. Foliar Mn accumulation in eastern Australian herbarium specimens: prospecting for 'new' $\mathrm{Mn}$ hyperaccumulators and potential applications in taxonomy. Annals of Bot. 2009; 103: 931-939.

30. Baker AJM, Brooks RR. Terrestrial higher plants which hyperaccumulate metal elements: a review of their distribution, ecology, and phytochemistry. Biorecovery. 1989; 1: 81-126. 
31. Jaffre T. Accumulation du manganese par les Protcacccs dc Nouvelle Calcdonie. Complex Rendus de I' Academic des Sciences, Paris, Seriel. 1979; 289: 425-428.

32. Jaffre T. Etude Ecologique du Peuplement Vegetal des Sols Derives de Roches Ultrabasiques en Nouvelle Caledonie. ORSTOM, Paris. 1980; 273.

33. Jaffre T. Accumulation du manganese par les cspcccs associees aux terrains ultrabasiqucs de Nouvelle Calcdonie. Complex Rendus de i' Academic des Sciences, Paris, Serie D. 1977; 284: 1573-1575.

34. Brooks RR, Trow JM, Vcillon JM, Jaffre T. Studies on manganese accumulating Alyxia from New Caledonia. Taxon. 1981; 30: 420-423.

35. Xue SG, Jun W, Zhou X, Liu H, Chen Y. A critical reappraisal of Phytolacca acinosa Roxb. (Phytolaccaceae) - A manganese-hyperaccumulating plant. Acta Ecologica. Sinica. 2010; 30: 335-338.

36. Hua D, Shun LM, Xu CY, Ping LY, Ming YF. A new discovered manganese hyperaccumulator - Polygonum pubescens Blume. Fresenius Environ Bull. 2010; 19: 94-99.

37. Liu P, Tang X, Gong C, Xu GD. Manganese tolerance and accumulation in six Mn hyperaccumulators or accumulators. Plant Soil. 2010; 335: 385-395.

38. Xie Q, Li Z, Yang L, Lv J, Jobe TO, Wang Q. A newly identified passive hyperaccumulator Eucalyptus grandis $\times E$. urophylla under Manganese Stress. PLoS ONE. 2015; 10: e0136606.

39. Kehui L, Yu F, Chen M, Zhou Z, Chen C, Li MS, et al. A newly found manganese hyperaccumulator-Polygonum lapathifolium Linn. Inter $J$ Phytoremedi. 2016; 18: 348-353.

40. Marschner P. Marschner's Mineral Nutrition of Higher Plants. Boston, MA Academic Press 2012.

41. Socha AL, Guerinot ML. Mn-euvering manganese: the role of transporter gene family members in manganese uptake and mobilization in plants. Frontiers in Plant Sci, Plant Nutr. 2014; 5: 106

42. Kogelmann W, Sharpe W. Soil acidity and manganese in declining and nondeclining sugar maple stands in Pennsylvania. J Environ Qual. 2006; 35 $433-441$

43. Marschner H. Mineral Nutrition of Higher Plants. Academic Press, San Diego 1995; 889

44. Boojar MMA, Goodarzi F. Comparative evaluation of oxidative stress status and manganese availability in plants growing on manganese mine. Ecotox Environ Safety. 2008; 71: 692-699.

45. Lambers H, Hayes PE, Laliberte E, Oliveira RS, Turner BL. Leaf manganese accumulation and phosphorus-acquisition efficiency. Trends Plant Sci. 2015 20: 83-90.

46. Ducic T, Polle A. Transport and detoxification of manganese and copper in plants. Braz J Plant Physiol. 2005; 17: 103-112.

47. Humphries J, Stangoulis J, Graham R. Manganese. In: A. Barker, D. Pilbeam (eds). Handbook of Plant Nutrition, Taylor and Francis, USA. 2007; 351-366.

48. Xu X, Yang J, Zhao X, Zhang X, Li R. Molecular binding mechanisms of manganese to the root cell wall of Phytolacca americana L. using multiple spectroscopic techniques. J Hazard Mater. 2015; 296: 185-191.

49. Pollard AJ. Heavy metal tolerance and accumulation in plants of the southeastern United States. Castanea. 2016; 81: 257-269.

50. Godo GH, Reisenauer HM. Plant effects on soil manganese availability. Soil Sci Soc Amer J. 1980; 44: 993-995.

51. DeGroote KV, Grace L, McCartha A, Pollard J. Interactions of the manganese hyperaccumulator Phytolacca americana L. with soil $\mathrm{pH}$ and phosphate. Eco Res. 2017

52. Lovley DR, Ueki T, Zhang T, Malvankar NS, Shrestha PM, Flanagan KA Geobacter: the microbe electric's physiology, ecology, and practical applications. Adv Microb Physiol. 2011; 59: 1-100.

53. Vega NWO. A review on beneficial effects of rhizosphere bacteria on soil nutrient availability and plant nutrient uptake. Rev Fac Nal Agr Medellín.
2007; 60: 3621-3643

54. Carmichael SK, Brauer SL. Microbial diversity and manganese cycling: a review of manganese-oxidizing microbial cave communities. Life in extreme environment, De Gruyter, Boston, MA, PP. 2015; 137-160.

55. Mou D, Yao Y, Yang Y, Zhang Y, Tian C, Achal V. Plant high tolerance to excess manganese related with root growth, manganese distribution and antioxidative enzyme activity in three grape cultivars. Ecotoxi Environ Safety. 2011; 74: 776-786

56. Millaleo R, Díaz MR, Ivanov AG, Mora ML, Alberdi M. Manganese as essential and toxic element for plants: transport, accumulation and resistance mechanisms. J Soil Sci Plant Nutr. 2010; 10: 470-481.

57. Clarkson DT. The uptake and translocation of manganese by plant roots. In Graham RD, Hannam RJ, Uren NC, (eds.), Manganese in soils and plants. Kluwer Academic Publishers, the Netherlands. 1988; 101-111.

58. Xu XH, Yun S, Xu CY, Xue S, Wu B, Huang Y. An investigation of cellular distribution of manganese in hyperaccumulator plant Phytolacca acinosa Roxb: using SRXRF analysis. J Environ Sci. 2006; 18: 746-775.

59. White PJ, Bowen HC, Demidchik V, Nichols C, Davies JM. Genes for calciumpermeable channels in the plasma membrane of plant root cells. Biochem Biophys Acta. 2002; 1564: 299-309.

60. Peng K, Luo C, You W, Lian C, Li X, Shen Z. Manganese uptake and interactions with cadmium in the hyperaccumulator-Phytolacca americana $\mathrm{L}$. J Hazard Mater. 2008; 154: 674-681.

61. Dou C, Fu X, Chen X, Shi J, Chen Y. Accumulation and interaction of calcium and manganese in Phytolacca americana. Plant Sci. 2009; 177: 601-606.

62. Pedas P, Husted S, Skytte K, Schjoerring JK. Elevated phosphorus impedes manganese acquisition by barley plants. Front Plant Sci. 2011; 2: 37.

63. Ghaderian SM, Ghasemi R, Hajihashemi F. Interaction of nickel and manganese in uptake, translocation and accumulation by the nickelhyperaccumulator plant, Alyssum bracteatum (Brassicaceae). Austr J Bot. 2015; 63: 47-55.

64. Kopittke PM, Lombi E, McKenna1 BA, Wang P, Donner E, Webb RI, et al. Distribution and speciation of $\mathrm{Mn}$ in hydrated roots of cowpea at levels inhibiting root growth. Physiol Plant. 2013; 147: 453-464.

65. Kopittke PM, Menzies NW, Wang P, McKenna BA, Wehr JB, Lombi E, et al. The rhizotoxicity of metal cations is related to their strength of binding to hard ligands. Environ Toxicol Chem. 2014; 33: 268-277.

66. Sasaki A, Yamaji N, Yokosho K, Ma JF. Nramp5 is a major transporte responsible for manganese and cadmium uptake in rice. Plant Cell. 2012; 24: $2155-2167$.

67. Ishimaru Y, Takahashi R, Bashir K, Shimo H, Senoura T, Sugimoto K. Characterizing the role of rice NRAMP5 in manganese, iron and cadmium transport. Sci Rep. 2012; 2:286

68. Cailliatte R, Schikora A, Briat JF, Mari S, Curie C. High-affinity manganese uptake by the metal transporter NRAMP1 is essential for Arabidopsis growth in low manganese conditions. Plant Cell. 2010; 22: 904-917.

69. Takahashi M, Sugiura M. Strategies for uptake of a soil micronutrient, manganese, by plant roots. RIKEN Rev. 2001; 35: 76-77.

70. Williams LE, Pittman JK. Dissecting pathways involved in manganese homeostasis and stress in higher plant cells. R. Hell and R.R. Mendel (eds.), Cell Biology of Metals and Nutrients, Plant Cell Monographs. 2010: 17.

71. Dou CM, Fu XP, Chen XC, Shi JY, Chen YX. Accumulation and detoxification of manganese in hyperaccumulator Phytolacca Americana. Plant Biol. 2009; 11: $664-670$.

72. Pedas P, Ytting CK, Fuglsang AT, Jahn TP, Schjoerring JK, Husted S Manganese efficiency in barley: identification and characterization of the metal ion transporter HvIRT1. Plant Physiol. 2008; 148: 455-466.

73. Murata Y, Harada E, Sugase K, Namba K, Horikawa M, Ma JF. Specific transporter for iron (III)-phytosiderophore complex involved in iron uptake by barley roots. Pure Appl Chem. 2008; 80: 2689-2697. 
74. Araki R, Murata J, Murata Y. A novel barley yellow stripe 1-like transporter (HvYSL2) localized to the root endodermis transports metal-phytosiderophore complexes. Plant Cell Physiol. 2011; 52: 1931-1940.

75. Pinto E, Isabel MPL, Ferreira VO. Cation transporters/channels in plants: Tools for nutrient biofortification. J Plant Physiol. 2015; 179: 64-82.

76. Yao Y, Xiao X, Ou Y, Wu X, Xu G. Root transcriptome analysis on the grape genotypes with contrast translocation pattern of excess manganese from roo to shoot. Plant Soil. 2015; 387: 49-67.

77. Gustin JL, Zanis MJ, Salt DE. Structure and evolution of the plant cation diffusion facilitator family of ion transporters. BMC Evol Biol. 2011; 11: 76.

78. Delhaize E, Gruber BD, Pittman JK, White RG, Leung H, Miao Y. A role for the AtMTP11 gene of Arabidopsis in manganese transport and tolerance. Plant J. 2007; 51: 198-210.

79. Page V, Weisskopf L, Feller U. Heavy metals in white lupin: uptake, rootto-shoot transfer and redistribution within the plant. New Phytol. 2006; 171 329-341.

80. Fernando DR, Marshall AT, Forster PI, Hoebee SE, Siegele R. Multiple metal accumulation within a manganese-specific genus. American J Bot. 2013; 100: $690-700$.

81. Donchevaa SPC, Stoyanovaa ZI, Georgievaa K, Velichkovac M, Barcelób J. Silicon amelioration of manganese toxicity in Mn-sensitive and Mn-toleran maize varieties. Environ Exper Bot. 2009; 65: 189-197.

82. Fernando DR, Woodrow IE, Baker AJ, Marshall AT. Plant homeostasis of foliar manganese sinks: specific variation in hyperaccumulators. Planta. 2012; 236: 1459-1470.

83. Fernando DR, Mizuno T, Woodrow IE, Baker AJM, Collins RN. Characterization of foliar manganese $(\mathrm{Mn})$ in $\mathrm{Mn}$ (hyper) accumulators using X-ray absorption spectroscopy. New Phytol. 2010; 188: 1014-1027.

84. Fernando DR, Batianoff GN, Baker AJ, Woodrow IE. In vivo localization of manganese in the hyperaccumulator Gossia bidwillii (Benth.) N. Snow \& Guymer (Myrtaceae) by cryo-SEM/EDAX. Plant Cell Environ. 2006; 29 : 1012-1020.

85. Fernando DR, Bakkaus EJ, Perrier N, Baker AJM, Woodrow IE, Batianoff GN, et al. Manganese accumulation in the leaf mesophyll of four tree species: A PIXE/EDAX localization study. New Phytol. 2006; 171: 751-758.

86. Fernando DR, Woodrow IE, Jaffre T, Dumontet V, Marshall AT, Baker AJ. Foliar manganese accumulation by Maytenus founieri (Celastraceae) in its native New Caledonian habitats: Populational variation and localization by X-ray microanalysis. New Phytol. 2008; 177: 178-185.
87. Blamey F, Pax C, Maria C, Soriano M, Cheng M, Tang C, et al. SynchrotronBased Techniques Shed Light on Mechanisms of Plant Sensitivity and Tolerance to High Manganese in the Root Environment. Plant Physio. 2015; 169: 2006-2020.

88. Xu XH, Shi JY, Chen XC, Chen YX, Hu TD. Chemical forms of manganese in the leaves of manganese hyperaccumulator Phytolacca acinosa Roxb. (Phytolaccaceae). Plant Soil. 2009; 318: 197-204.

89. Dou C, Fu X, Chen X, Shi J, Chen Y. Accumulation and interaction of calcium and manganese in Phytolacca americana. Plant Sci. 2009; 177: 601-606.

90. Fecht-Christoffers MM, Maier P, Horst WJ. Apoplastic peroxidases and ascorbate are involved in manganese toxicity and tolerance of Vigna unguiculata. Physiol. Plant. 2003; 117: 237-244.

91. Gao L, Kejian Peng, Yahua C, Guiping Wang, Zhenguo Shen. Roles of apoplastic peroxidases, laccases, and lignifications in the manganese tolerance of hyperaccumulator Phytolacca Americana. Acta Physiol Plant. 2012; 34: 151-159.

92. Zhao H, Liangqi Wu, Tuanyao Chai, Yuxiu Zhang, Jinjuan Tan, Shengwen M. The effects of copper, manganese and zinc on plant growth and elemental accumulation in the manganese-hyperaccumulator Phytolacca americana. Journal of Plant Physiology. 2012; 169: 1243-1252.

93. Weng $X Y$, Zhao LL, Zheng $C J$, Zhu JW. Characteristics of the hyperaccumulator plant Phytolacca acinosa (Phytolaccaceae) in response to excess manganese. J Plant Nutr. 2013; 36: 1355-1365.

94. Mittler R. Oxidative stress, antioxidants and stress tolerance. Trends Plant Sci. 2002; 7: 405-410

95. Gill SS, Naser A Anjum, Iqbal Ahmad, P Thangavel, G Sridevi, M Pacheco, Armando C. et al. Metal Hyperaccumulation and Tolerance in Alyssum, Arabidopsis and Thlaspi: An Overview. N.A. Anjum et al. (eds.), the Plan Family Brassicaceae: Contribution towards Phytoremediation, Environmental Pollution 21, \# Springer Science+Business Media B.V. 2012.

96. Brooks RR .Plants that hyperaccumulate heavy metals. CAB International Wallingford. 1997; 88-105.

97. MCQuattie CJ, Schier GA. Response of sugar maple (Acer saccharum) seedlings to manganese. Canad J Forest Res. 2011; 30: 456-467.

98. National Department of Mineral Production (DNPM. Annual summary. 2015. 